University of Wollongong

Research Online

Faculty of Social Sciences - Papers (Archive) Faculty of Arts, Social Sciences \& Humanities

2016

Transplanting, plotting, fencing: relational property practices in community gardens

Eleonora van Holstein

University of Wollongong, emvh894@uowmail.edu.au

Follow this and additional works at: https://ro.uow.edu.au/sspapers

Part of the Education Commons, and the Social and Behavioral Sciences Commons

Research Online is the open access institutional repository for the University of Wollongong. For further information contact the UOW Library: research-pubs@uow.edu.au 


\title{
Transplanting, plotting, fencing: relational property practices in community gardens
}

\author{
Abstract \\ Community gardening is an increasingly popular phenomenon. Local governments wishing to 'green' the \\ city and make the urban environment more 'inclusive' sometimes promote community gardening as a \\ means to meet policy goals. Scholars from various fields have been keen to focus on these positive \\ promises of community gardening. However, community gardens are not inherently different from their \\ surroundings or good in themselves as they are connected to wider urban landscapes and routines \\ through practice. Building on empirical research that I conducted at three community gardens in Sydney, \\ Australia, I reveal how property is practised in three gardens with different property models, focussing on \\ three practices - transplanting, plotting and fencing. I show that community gardeners produce property \\ relationally and that through each of these practices, they create overlapping understandings of common \\ and private property. Gardeners have contradictory motivations that are geared both towards community \\ inclusion and the protection of personal interests. The paper reveals that while feelings of ownership \\ contribute to a sense of community belonging, they also help legitimatise a defensive and exclusive \\ spatial claim.

\section{Disciplines} \\ Education | Social and Behavioral Sciences

\section{Publication Details} \\ van Holstein, E. (2016). Transplanting, plotting, fencing: relational property practices in community \\ gardens. Environment and Planning A, 48 (11), 2239-2255.
}


1 Transplanting, plotting, fencing: relational property practices in community gardens

By Ellen van Holstein - University of Wollongong

4

$5 \underline{\text { Abstract }}$

6 Community gardening is an increasingly popular phenomenon. Local governments wishing

7 to 'green' the city and make the urban environment more 'inclusive' sometimes promote community gardening as a means to meet policy goals. Scholars from various fields have

been keen to focus on these positive promises of community gardening. However, community gardens are not inherently different from their surroundings or good in themselves as they are connected to wider urban landscapes and routines through practice. Building on empirical research that I conducted at three community gardens in Sydney, Australia, I reveal how property is practised in three gardens with different property models, focussing on three practices - transplanting, plotting and fencing. I show that community gardeners produce property relationally and that through each of these practices they create overlapping understandings of common and private property. Gardeners have contradictory motivations that are geared both towards community inclusion and the protection of personal interests. The paper reveals that while feelings of ownership contribute to a sense of community belonging, they also help legitimatise a defensive and exclusive spatial claim.

\section{$\underline{\text { Introduction }}$}

Urban community gardens are collectively managed urban spaces where people garden together or alongside each other. Other than allotment and victory gardens, community gardens are strongly associated with grassroots initiative, and traditionally exist in tension with formal urban land use regulations before they are either evicted or formalised (see 
1 Staeheli and Mitchell, 2008). However, local governments are becoming more hospitable to community gardens and increasingly include these projects in policy documents.

Governments do this for a variety of reasons, for example because community gardens are thought to have various beneficial outcomes for citizens and neighbourhoods, such as healthy lifestyle choices (Guitart and Pickering, 2014), environmental awareness (Turner, 2011) and cost-efficient upkeep of green space (Rosol, 2012). The association of community gardens with social capital, community resilience and social inclusion, has perhaps been most influential in encouraging local governments to adopt this grassroots phenomenon into policy (see Kingsley and Townsend, 2006).

A substantive branch of social science literature on community gardens approaches these projects optimistically with regard to their inclusive characteristics and capacity to foster resilient communities (Beilin and Hunter, 2011; Firth et al., 2011; Glover et al., 2005; Holland, 2004). Policymakers adopt this optimistic outlook. In Sydney, Australia, where this paper takes its empirical focus, most local councils encourage citizens to join or start a community garden. As reasons for people to join a community garden, their websites mention benefits such as waste management, access to fresh food, and that community gardens potentially bring community members together (for an example see City of Sydney, 2016). These messages stand in stark contrast with my fieldwork experiences. Attempting to be involved in community gardens, the exclusionary effects of community gardens become immediately noticeable as I bump into fence after fence. Sometimes a sign directs me to a website or provides me with a phone number. However, in neither of the three field sites in which I eventually get involved is access straightforward. Community gardeners I meet in these gardens often bring up this issue. One community gardener for example describes the project in her neighbourhood as 'a gated community' in which the gardens do not achieve to create a sense of community, because it feels like an exclusive club of gardeners. Other 
gardeners consider exclusive access to the garden fair because the people who invest in the garden should be rewarded for their effort.

Taking its cue from recent developments in property research, this paper builds on the insight that property and associated rights to include or exclude are not absolute, but constantly subject to changing enactments and interpretations that can make property do different kinds of work with both inclusive and exclusive effects (Blomley, 2004; 2015). As Staeheli and Mitchell (2008) argue, no community or public can exist without exclusion. Rather than accepting the inclusionary characteristics attributed to community gardens, or judging the exclusionary practices of community gardeners as materialized in garden fences, I ask how community gardens sit in a wider landscape of property relationships and what kinds of property relationships are produced through gardening practices and gardeners' movement between different property spaces. These explorations lead to the main argument that community gardening practices are partly motivated by community objectives but equally relate to private gardening practices and to gardeners’ personal lives. Gardeners produce understandings of property relationally which leads to contradictory motivations and relationships that are at once geared towards community belonging and personal interest. Consequently, the current support for and scepticism towards community gardens can be replaced with a more nuanced consideration of the property practices these spaces facilitate and what the effects of those practices are.

First I conceptually frame community gardens as spaces for studying the complexity of property practices and relationships. I then move on to an exploration of community gardening in the Inner West of Sydney. After an introduction of the field sites, I identify three property practices that came forth out of the empirical work - transplanting, plotting and fencing. I use these practices to guide a discussion about property relations in and around 
1 community gardens and shed critical light on discourses in which the 'community' aspect of

2 community gardening is put forward as inherently inclusive.

$4 \quad$ The complexity of property relationships

5 The concept of property has an extensive theoretical history encompassing various

6 approaches towards understanding what it means to own something. Most recent

7 developments emphasize the contextual and complex nature of property relationships (e.g.

8 Blomley, 2016). Even in its most simplified form - an individual right to exclude others from

9 a particular thing or resource - property requires that people understand property rules and

10 conditions regarding access to goods and other resources (Rose, 1994). Or in Blomley’s

11 words (2016, page 227): 'Property is only good against the world if lay people understand the nature of the rights to which it is attached'. Even when approached as an individual entitlement, property is an inherently communicative and hence social phenomenon. This is why Rose (1994) argues that any private property regime as a whole is common property shared among its subscribers. This key insight illustrates how property is more complex than an individual's exclusive right to access or use something.

Complexity also plays out where vernacular understandings and workings of property are substantially different from formal or bureaucratic inscriptions of property. Property practices might then exist in tension with formally inscribed property rights. For example Blomley (2004) shows how private property holders adopt adjacent public spaces through their gardening practices. Private gardeners inscribe a layer of private property practices onto public space without an agenda to gain formal ownership, thus creating a complex meshwork of informal property relationships with other neighbours and passers-by. This insight is important because law has an interactive relationship with everyday 
1 'continues on through causal chains into the world of stuff' where it affects real matter and

2 real life (Delaney, 2002, page 78). Concurrently, a strong effect of property is that it makes

itself seem natural, secure and fair to the extent that it masks the exclusion, injustice and reliance on community resources that were necessary to create an illusion of stability (Blomley, 2013; Nedelsky, 1990). So although research shows that many property relationships are shaped by and affect community dynamics, the private property regime in which property is understood as the exclusive right of one person to exclude others, remains dominant. This effect is described as the agency of property itself (Blomley, 2013).

The tendency of property to make itself seem natural combined with its power to affect real life creates a need for ethnographic research that uncovers how property is practised in everyday life, how the effects of those practices are felt and how people make sense of its results (Blomley, 2015; 2016).

\section{Property as practice}

Aside from asking what property represents, researchers ask through which practices naming, fencing, repairing and policing - property is made and what property subsequently makes people do (Blomley 2015; Lang, 2014 Wekerle and Classens, 2015). A focus on practice shows how in everyday life people put property to use in ways that transgress the two classical categories of private and public property. Private entitlements are partially waived for the sake of common interest (Lang, 2014; Wekerle and Classens, 2015) and conversely, people take responsibility over public space through private property practices in order to take temporary control over common areas (Blomley, 2004; Lang, 2014). Gardening is one set of practices which allows social scientists to explore the production of ownership (e.g. Cerwonka, 2004; Lang, 2014). Spatial practices such as weeding and planting situate subjects in place and create an imagined sense of community 
1 tied to a certain territory (Cerwonka, 2004). At the same time scholarship shows the

2 transgressive potential of these practices, for example where gardeners care for plants beyond the private property fence (Head and Muir, 2006). Lang (2014) provides insight into how the

sharing and caring for plants across private yards produces understandings of private

properties as shared spaces and that these understandings might differ from legal

representations of property. Property scholarship reveals the inclusive and exclusive capacities of property practices and draws attention to the instrumental role of plants in the constitution of property relationships.

Research on urban agriculture shows that gardening practices are potentially radical which might subvert the hegemony of neoliberal market logic and modes of thought.

Gardening practices open up private spaces to be used by third parties and in ways that can exist outside the dominant market (Naylor, 2012; Lang, 2014; Wekerle and Classens, 2015). There are hopeful expectations that practices of commoning might enable more inclusive and ecologically just food chains. At the same time urban gardening and other alternative agricultural practices relate to neoliberalism in problematic and contradicting ways (Guthman, 2004; Pudup, 2008; McClintock, 2014). For example because the very gardening practices that create independence also create an understanding of personal responsibility and accountability. Acknowledging that property is a complex construct that can be practised and play out in varying and contradicting ways, I argue that community gardeners’ property practices create entanglements of individualized and communal property relationships. This problematizes the idea of community gardens as commons.

\section{Community gardens as commons}

Community gardens are eccentric cases of property ownership. They 'transcend the separation between the public and the private’ (Schmelzkopf, 1995, page 379), and 
1 complicate the relationships between private ownership and the public good (Lawson, 2007).

2 In the past, community gardens have proven to be constructive community spaces in impoverished urban environments, and have therefore been flagged as a spatial materialisation of the right to the city (Schmelzkopf, 1995; 2002; Staeheli and Mitchell, 2008). In light of these benefits, community garden researchers advocate for security of tenure, especially where projects are situated in decaying urban landscapes and are functioning as spaces of empowerment for marginalised social groups (e.g. Schmelzkopf, 1995; 2002; Staeheli and Mitchell, 2008).

In line with this, urban agriculture and alternative food scholars celebrate community gardens as inclusive examples of food production sites. The uneasy fit of many community gardens with a binary private versus public approach to property makes researchers put these projects forward as shared resources or as commons (Eizenberg, 2012). One of the central property issues community garden scholars grapple with is the relation between shared community garden spaces on the one hand and the market and governance landscapes in which they are situated on the other. Community gardens are part of urban landscapes that are strongly shaped by market dynamics which complicates the protection of these spaces when they are used under temporary leases (Schmelzkopf, 2002; Staeheli and Mitchell, 2008; Eizenberg, 2012). Eizenberg (2012) analyses solutions to this dilemma and finds that through trusts and non-profit organisations it is possible for commons to exist in a neoliberal city that is largely governed on the basis of market dynamics. He contends that the commons, 'is a mechanism for redistribution through which underprivileged residents compensate themselves for uneven urban development' (Eizenberg, 2012, page 779).

Scholars recognise that community gardens might work towards individual gain when they work to increase property value (Staeheli and Mitchell, 2008; Quastel, 2009; Eizenberg, 2012). Quastel (2009, page 719) approaches gentrification and community gardens from a 
1 political ecology perspective and describes the 'obscene' situation in which the urban poor are rendered homeless to provide well-off green urban residents with a leisure space in which they can enact their 'individualized consumer response to environmental problems'. Quastel's work also shows that aside from social inclusion, empowerment and citizenship, community gardens might instead be stripped from their transformative potential and shape exclusive landscapes of property relationships.

To generate a deeper understanding of property relationships associated with community gardens, I wish to build on the insight generated by these studies that have focussed on institutional management of community gardens. Attention to gardeners’ practices particularly relating to fences and plots has proven a fruitful approach towards understanding the meanings that are embedded in these community spaces through everyday enactments. Previous work has done so for example by asking how people understand 'community' based on the compartmentalisation of responsibilities, entitlements and garden space (Klein, 1993; Kurtz, 2001). Although property is not explicitly mentioned in these studies, the work does show how property devices such as plots and fences shape a sense of community (Kurtz, 2001). Plots also illustrate some of the controversies in community gardens around the policing of borders and social norms, and draw attention to gardens as spaces of conflict rather than community sanctuaries (Klein, 1993). Kurtz (2001) highlights how community gardeners enclose their garden, and how groups of gardeners redefine the meaning of 'garden' and 'community’ whilst erecting physical boundaries and policing social norms surrounding membership and access.

Recent developments in property theory offer an alternative approach in considering property as produced through practice. Those developments enable me to focus on gardening practices and gardeners' experiences in the wider landscape while keeping property in and outside the garden in sight. An everyday practice approach to understanding property 
1 relationships in community gardens makes insightful how community gardens and gardening

2 practices are connected to other property spaces. The approach reveals the overlapping and relational meanings that are generated through property practices; it shows how these

4 relations work out and to whose benefit. Critiques of community gardens that interpret these projects as either transformative or neoliberal spaces both overlook how these gardens are connected to their environments through practice. With the paper's focus on practice it aims to bridge the gap between optimistically hopeful and sceptically critical interpretations of community gardens.

In the remainder of this paper I explore and discuss gardening and property practices in three community gardens and gardeners' nearby private properties to reveal the ways in which property shapes relationships in community spaces such as shared gardens. The analysis works to support the main argument that practices of property are relational and both inclusionary and exclusionary.

\section{$\underline{\text { Researching community garden practices }}$}

This paper draws on research conducted at three community gardens in Sydney, Australia. City of Sydney council encourages community gardening in various policy documents. Their policy acknowledges the importance of 'community ownership' for the long term success of these projects and facilitates this sense of ownership in letting community groups manage the gardens themselves (City of Sydney, 2016). Consequently it does not dictate how garden groups should organise ownership or responsibilities, nor does it consider how 'community ownership’ might entangle or conflict with personal ownership or interest.

The three selected gardens have different management models in terms of organisation into shared areas and individual plots. This particular characteristic directed the selection of gardens for this study because several participants mentioned that they based 
1 their choice to join a particular garden on its model. The different combinations of shared spaces and plots in the gardens also helped reveal some property practices and related feelings of community belonging that were specific to a garden's model.

The first garden was established as a guerrilla garden to block housing development and predominantly consists of private plots. I will refer to this garden as Stanley Road

6 Garden. The garden appears locked but is easily accessible for informed gardeners. People can join the project through Claire, the protagonist and gatekeeper of the project who allocates plots. ${ }^{1}$ The second garden is a communal garden that was started in 1992 with a

3000 Australian dollar grant from South Sydney Council to propagate native plants and improve waste management. I will refer to this garden as Park Street Garden. At this garden, volunteers have the code to a numeric padlock on the gate but are also encouraged to attend weekly communal gardening hours. The third garden was established in 2013 and consists of a mix of private plots and communal areas. I will refer to the garden as Highfield Garden. At this garden the community collects an annual membership fee of 40 dollars per person and charges 80 dollars rent per plot. The garden was started with a council grant of 15.000 Australian dollars.

Fieldwork consisted of participant observation during working bees that are semiregularly held at each of these three gardens. Parallel to observatory fieldwork, twenty-five people were interviewed at these gardens. Fourteen interviewees were owner-occupiers and seven rented their dwelling. The sample of participants included sixteen people with university degrees, four with a college diploma and one with a high school diploma. Sixteen participants identified as Oceanian, four as North-West European and one as North-East Asian. Four participants did not share demographic information.

\footnotetext{
${ }^{1}$ Where gardeners requested not to be identified pseudonyms were used.
} 
Fourteen of the interviews included a walk from the gardener's private garden to the community garden. The walking interview is a suitable method for studying community gardens because community gardens are connected to the social and physical fabric of the city (Kurtz, 2001). As a mobile method, the walking interview is a fitting way to explore these connections, because 'by tracking the natural sequence of places in practical everyday life, go-alongs enhance our understandings of how individuals connect and integrate the various regions of their daily lives and identities’ (Kusenbach, 2003, page 478).

Although the interview schedules and mobile research methods were not developed with the aim to uncover property relationships and practices, property quickly emerged as a prominent theme. The research methods were arguably sensitive to bring out this theme for two reasons. First, walking provides an 'intimate vantage point for reconstructing the dynamics of interaction in communal and private realms' and sheds light on everyday politics of neighbourhood belonging (Kusenbach, 2003, page 466, also see Waitt et al., 2009). Second, the neighbourhoods in which the community gardens are located continue to go through substantial changes in property relationships. The contemporary landscape of property relationships in Australian cities is shaped by a deep history of dispossession. Additionally, the urban landscape in which the three community gardens are situated, Sydney's Inner West, is characterised by strongly increasing residential property values and changes to the neighbourhoods' demographic profile (Atkinson et al., 2011). Community gardeners in this study are part of this dynamic either as newcomers to the area or as observers of the changes to their neighbourhood.

The gardens are located in a relatively dense area with neighbourhood density ranging from $53.47^{2}$ to 101.91 persons per hectare (City of Sydney, 2011). The residents of these neighbourhoods predominantly live in medium-density housing (6007 dwellings) such as

\footnotetext{
${ }^{2}$ This number is substantially higher for the residential area of the neighbourhood as approximately half of the neighbourhood is used for public infrastructure.
} 
1 terraced and semi-detached houses, many of which have a backyard. The second largest

2 group of dwelling type in the neighbourhoods is high-density apartments (4034 dwellings) and the amount of detached low-density housing is small (765 dwellings) (City of Sydney, 2011). The density of these neighbourhoods has increased since gentrification processes started to affect the area in the 1970s, encouraging housing development on fill-in and

6 formerly industrial sites. Rising property values encourage owners to invest in their residential properties. Investments such as renovations and extensions were frequently brought up by interviewees as these affected gardening practices. One participant explains he joined the community garden in search of more growing space: 'And we also have a, quite a large group of friends and I have on my side a big family and so we built the house so that we could basically open up these doors and if we want to have thirty people here anytime we can. So it’s really, and you know, a space to entertain as well as to grow things’. (Lucas, 39, Highfield Garden)

Another gardener mentions that the investment of a neighbour in building a second storey on the adjacent property overshaded his backyard to such an extent that he had to seek garden space in the community garden.

Other participants are conscious observers of how property interests change their residential area. Participants comment on rising costs of living in the area, the increasing pressure on available land, the neighbourhood's changing demographic composition and the role of the community garden in attracting gentrifying homeowners. Even when newcomers might not be interested in gardening themselves, they understand the community garden as having a positive effect on the value of their property. This urban landscape shaped a research project that sheds light on how private and community understandings of property are connected through everyday routines and practices. 
I now discuss three property practices: transplanting plants between private and communal spaces, constructing garden plots and fencing. These practices illustrate how community spaces are inclusionary as well as exclusionary, and how meanings of home and community garden spaces are relationally produced.

\section{Transplanting; moving between home and communal space}

Community gardens are closely connected to a wider urban environment that is shaped by property relationships. For example, community gardens are strongly connected to the scale of the neighbourhood, as in many of these gardens membership is exclusively available to people who live near the site. Where such rules are not in place, the practicality of everyday routes and routines makes it more favourable for people to join a garden close to where they live. The practice of transplanting plants between private backyard and community garden illustrates how people enact those connections between home and communal space and make sense of different property spaces. In this section I reflect on the practice of moving plants between gardens and on the effects of spatial-proximity which facilitates this practice.

Residential proximity and the time this allows people to invest into the space result in feelings of ownership. Living directly across the street from the mixed plot garden, Sophie expresses a heightened sense of responsibility and ownership based on the short distance between her private residential home and the community garden:

I feel a little bit proprietal about the garden. [...] I feel a sense, a greater sense of ownership of the garden than my own plot. Because I am so, across the road and I've been involved with it. And I walk in and I look sort of at the whole not just, oh, what is happening in my plot. (Sophie, 43, Highfield Garden)

This quote illustrates how community gardens relate to private spaces and how those relations shape gardening practices and feelings of ownership. It also shows that this sense of 
1 ownership is not straightforwardly exclusionary or private. Sophie expresses a sense of responsibility over the wider community space, not just her own plot, based on the proximity of her home.

Additionally, gardeners connect home gardens and community gardens through everyday gardening practices and routines. Movement between home and community garden allows them to extend practices from one space into the other. Most participants describe at least some home gardening practices, and these frequently entangle with community gardening practices. The gardeners who describe their own garden and the community garden as completely separate often have - either physically or in terms of sun hours - very limited space to garden at home. Different meanings ascribed to home and community garden space lead to people growing different kinds of plants in each space. At his home garden, Lucas for example mentions:

'It's so sheltered and shaded we just can't grow anything here. And that's why we wanted to join the plot, so that we can grow some stuff. Yeah so the garden here is basically just a place where we kind of relax and hang out'. (Lucas, 39, Highfield Garden)

Lucas chooses to grow food at the community garden and flowers at his home garden because his home garden is too shaded for edible crops to flourish all year round. At the private plot garden. Claire puts forward a similar reasoning. When I ask her whether she grows different things in the two spaces, she says:

'Well yes because there is more space here [in the community garden] and I tend to try and keep this my space here for edible things [...] because [at home] you might want to have some screening plants or you know different plants but not that you can necessarily eat. So here you can grow just to eat’. (Claire, age unknown, Stanley Road Garden) 
However, it is more common for people to understand the private and communal spaces as in some way connected. People often start gardening communally when they realise they have limited garden space at home and this encourages them to carry private gardening practices and plants into the shared garden. Ben for example says:

'So I was always interested in gardening and my neighbours were putting up a two storey extension which is all my sunlight. So all the synergies were there. These guys [the gardeners] needed help. I needed to move my plants which I had been nurturing for 22 years into a place where they could survive. [...] And because my garden has been overshaded by my neighbour's next door. I want to basically come here, sit in the sun in the winter and potter in the garden. What I used to do in my own backyard. So it saves my backyard.’ (Ben, 55, Park Street Garden)

Many gardeners move back and forth between community and home garden, people transplant plants between these garden spaces and this way the meaning of the community garden and the gardening practices that take place there are produced in relation to private backyards. At the communal garden, Ben for example says: 'I’m thinking of moving soon and some of the plants I've got that are doing pretty well that I won't be able to take with me because the place I'm moving is probably smaller I would probably try to give them a new home here. And also sometimes if something is growing well here and you'd kind of want to have one yourself you can try to take it back and see if you can get it to grow.' (Ben, 38, Park Street Garden)

These practices of sharing, appropriating and transplanting plants produce relations that transgress the boundaries of private property and community space. Plants are sometimes moved from the private backyard or balcony into the community garden if they need more sunlight or space to grow. 

community garden is when a plant requires more attention. People move plants home during precarious stages of the plant's life and prefer to grow fragile seedlings from home, because this allows continuous monitoring. While people are motivated to be part of a community project, home growing is easier to incorporate into daily routines. Water and equipment are more readily available and seeing plants on a daily basis is a handy reminder of their needs. Stephanie for example takes struggling plants home: 'So sometimes what I used to do, is that anything that looks like it's dying I would take home. Every plant, I'd take home and I'd nurse it at home. [...] because where my garden at home is, it’s at my front door. I walk past it, my hose is right there. I go to take the bin out, I see it. I go to take the girls out, which I do at least once a day, I see it. I give it water. I did mix up pesticide, garlic and soapy water. And I had it here to spray. And then when I took a few things home I found it easier’. (Stephanie, 33, Stanley Road Garden)

People say the same thing about growing seedlings. Sarah at the mixed plot garden says: 'you can tend to it pretty much every day if you want to. So it makes it a bit easier to control it. [...] I certainly don't get to the community garden every day'. (Sarah, 48, Highfield Garden)

The ways in which gardening practices entangle with everyday routines, makes some people adjust their planting practices altogether. Alice says that she changed the plants in her plot altogether when she accidentally let everything in it die:

'I have been working so my garden died. [...] So then I replanted things that didn’t need to be crazy watered all the time'. (Alice, 23, Stanley Road Garden)

And Charles has an understanding of his private and community garden as spaces in which he can grow things that require different amounts of time and effort: 
'I just use this space to grow things that take a little bit more space or will grow a little bit more on their own. The last maybe two years I haven’t grown anything down here [in the community garden] that I didn’t think would survive at least a week, preferably two weeks without any tender love and care’. (Charles, 29, Park Street Garden)

\section{This spatial organisation of gardening practices allows people not to go to the garden very} often. This way of orchestrating everyday routines enables people to feel part of a community project while not having to change their lifestyle. Ironically, these very practices detract from the sense of community that people get from their involvement. One could even argue that it allows for community gardens to be masqueraded as community projects while those supposed ‘communities’ really do not exist. Stephanie wonders: 'I’ve been there for two, maybe longer now, two years and other than Claire I don't really see anybody in there. But I do see things happening. So whether these guerrillas are ninjas really’. (Stephanie, 33, Stanley Road Garden)

Sharing plants across private and communal boundaries has recently been identified by Lang (2014, page 853) as a practice that allows an 'interweaving of the logics of private property and commons'. Lang's study contributes to a larger endeavour to reveal the complexities of property beyond a formal private versus public dichotomy. In an attempt to counterbalance the dominance of the private ownership model, these studies pay attention to examples of formally private spaces that are turned into common space through everyday practice and public use. Lang's study is another example of how gardening tends to be approached as an open and inclusive practice. The practice of transplanting and the movement of gardeners between home and community gardens show that property is produced in complex relational ways and that these practices are directed by community motivations but also by personal routines and lifestyle objectives. Fitting ‘community’ into a personal everyday routine relies on private as well as communal space, which encourages 
people to enact their gardening practices back and forth between private and community spaces. The search for this balance is further illustrated by the practice 'plotting'.

\section{Plotting; understanding property in the context of community}

In all three gardens, the majority of gardeners value having control over a specific part of the garden. Even in the garden without plots, there is an informal understanding of which patches and plants belong to whom. Plots allow gardeners to fit communal gardening into their everyday lives, without risking intervention from other gardeners. The practice of gardening on plots illustrates how property helps people orchestrate a community project with a personal everyday routine. It helps people make sense of what is theirs to take, keep or share, and how they personally relate to the community project.

For many gardeners the advantage of having separate plots that clearly divide and communicate individual responsibilities is evident. Talking about the history of the garden and whether people wanted private plots from the start, Sophie at the mixed plot garden answers:

'I think no one even questioned that. [...] We were all very happy with that. I have been involved in a community garden prior to this when I was living in Glebe, [...] which was just a beautiful space, everything was communal but such a, it’s such a hassle because you plant something, someone takes it or you know someone else plants it, you take a bit, you know what I mean? It's just irritating. So I think the individual plot is much better. It's much, much better because people have control over what they want to grow when they grow and if it's a stuff up its their stuff up, it's just and people care for it a lot more I think.' (Sophie, 43, Highfield Garden)

Sophie puts forward an understanding of plants as things that are to be managed and taken by their owner only. She describes practices of sharing plants as irritating, and prefers the sense 
1 of security that comes with having control over a plot where other gardeners will not interfere. Private plots are understood as the only sensible way to organise a community project. Even in the communal garden, where private plots have not (yet) taken hold, Ben,

among other gardeners, is convinced that private plots would be better:

'Whereas I and Charles for example say pay 50 dollars, have your own little plot. And others say you don’t have individual plots, you have to share everything. So like the communist system, the efficiency is actually less I believe. Because no one takes care of the individual plots’. (Ben, 55, Park Street Garden)

He explains that the garden does have individual patches of responsibility:

'It's like a socialist um, collective garden where you cannot grow things just for yourself. But at the same breath we're told, well we know that if you're working a patch, no one else will touch it’. (Ben, 55, Park Street Garden)

This kind of understanding between gardeners about the autonomy they enjoy in certain areas of the garden emerged in all three gardens. Beth at the private plot garden said for example: 'I wouldn’t want to touch something that is someone else's. Even if it looks like they’ve left it forever. My garden, I was growing flax... linseed and it looked probably like it was a weed. [...] But it wasn't so I'm glad that someone didn't fix it. If you know what I mean. So I wouldn’t want to fix someone else’s plot when it’s not needing to be fixed.' (Beth, 28, Stanley Road Garden)

Beth illustrates how the plots are an important spatial device for managing personal lives while being involved in a shared project with people who have other routines. The quote also illuminates how the plots rely on mutual understanding and sympathy between gardeners who are trying to manage busy lives. Stephanie says she does not mind when fellow gardeners spend little time in the garden: 
'No, I guess if we were all in the same plot then yeah, but because we've got little sections, it doesn’t worry me’. (Stephanie, 33, Stanley Road Garden)

At all three gardens gardening on plots and the associated separation of responsibilities allow people to avoid gardening with others. This is particularly evident at the private plot garden, where the plots create a situation in which the gardeners only know the person who allocates the plots and none of the other members. The 'dispersed community', as one of the gardeners calls it, makes many express feelings of guilt and disappointment. Gardeners join the project seeking community connections but end up not finding the time to make those: 'I don’t know anyone else from the community garden, because I haven’t been able to go to any of the working bees because I have been working, so my garden died and I was like aaarggh. [...] I realized it's also my fault for not having been to the working bees'. (Alice, 23, Stanley Road Garden)

People value the possibility to work out their own routine and garden at times that are convenient for them. The system of plots allows people to come and go as they please because there is no need to negotiate with others. This means however that there is no incentive to attend working bees, resulting in the working bees becoming non-existent.

On the one hand the plot is an autonomous space that allows people to follow personal routines, but at the same time the plot is a spatial device that is constitutive of community. People feel that they acquire membership and belonging when moving onto their plot. Claire says that there are no barriers to becoming a member of the private plot garden group:

'There is no barriers. You just have to ask, and most people who have asked have come in and been able to take over a little plot, or build their own little plots and build up their own dirt and put their own seeds in.' (Claire, age unknown, Stanley Road Garden) 
1 The practice of building a plot is here singled out as a practice that creates membership and belonging to the group.

At the mixed plot garden, having a plot is also an important part of being a member. However, for 40 dollars a year it is also possible to be a general member without a plot. Payment for membership without the spatial claim on a plot does not seem to produce the same sense of group belonging. At the 2014 end of year meeting the secretary asks members to think about ways to encourage general members to be more involved, as some mentioned to her that they struggled to see their place and purpose in the community project. Zoe, who just started occupying a plot after two years of general membership explains that she started to feel a greater sense of belonging after she occupied a plot:

'I must say now that I've got my own plot I feel more comfortable coming here. I sort of wondered if I should be here or not as much as a general member. Which no one suggested that I shouldn't be, but I feel more, and I'm coming more often now, so I feel more comfortable, you know, more part of the place.' (Zoe, 47, Highfield Garden)

Zoe's statement illustrates the iterative relationships between practice, property and belonging. Being in the garden and having a spatial claim in the garden generates a sense of belonging which in turn encourages Zoe to be present in the garden more often.

Plots and individual responsibilities appear necessary because they give gardeners a sense of belonging as well as autonomy. Consequently, managing one’s own life and being part of the community becomes a delicate search for balance that is played out on the plot. Gardeners are aware that the autonomy that comes with plot ownership might facilitate withdrawal and that this could be detrimental to community cohesion. At the mixed plot garden, people have to garden during communal hours for an undefined period to prove that they have a 'genuine interest' in the community, or as Sophie puts this, they have to: 
'[have] shown that you are kind of in it actually for also the community bit not just your own gain’. (Sophie, 43, Highfield Garden)

Community gardeners enact a spatial division of plots that helps them constitute a sense of autonomy as well as group belonging. Although this might seem contradictory, Davies' feminist critique on property theory (2012) helps us see how the idea of ownership as vested in a bounded self is illusionary at best. Autonomy, she demonstrates, can only be reached in relation to others. In setting up plots of autonomy, gardeners find a way to be alongside as well as with others. This way gardeners balance community yearning with their personal lifestyles. The practice of plotting, while separating the garden space into isolated parcels, also contributes to a sense of common ownership as it enables people to be involved and creates a sense of togetherness. Property practices such as plotting, and resulting understandings of community, also translate into ways people see the entirety of their community garden as a space of entitlement that needs to be clearly demarcated and monitored. I will illustrate this in the next section where I discuss fencing.

\section{Fencing: protecting community and garden from undeserving others}

Where gardening on plots helps people manage and understand their own investments and daily routines in relation to, and as part of, the community project, fencing illustrates how people make sense of the group in relation to outsiders. The three gardens already had fences around the site when fieldwork commenced. In singling out fencing as a practice, I refer not only to the actual construction of those fences but more so to how people talk about the fence and legitimatise, enjoy or resent that fence. Fence talk sheds light on levels of comfort and unease with exclusivity, and illustrates how people make sense of 'community' in terms of both accessibility and enclosure. 
When asked about their opinions or feelings regarding the fence, most gardeners mention that no fence would be better but that unfortunately in the present situation the fence is necessary to keep unwanted others, such as drunks and vandals, out. Some gardeners also see the fence as a construction that legitimatises the project. At the private plot garden, the garden that was started without council support, Beth says about the fence that:

'I feel like the council has given me permission to be here. For the time being'. (Beth, 28, Stanley Road Garden)

When asked about the fence and connections between the garden and the neighbourhood, gardeners at all three projects tell stories about passers-by stopping, looking at the greenery and asking about the project through the fence. Gardeners interpret this as endorsements and as neighbours’ intentions to get involved later on. Henry says:

'I think it's great for passers-by. They don’t want to necessarily get in here in the first instance. Unless they're regulars. And then they think oh I want to be part of it'.

(Henry, 76, Stanley Road Garden)

This illustrates that although the fence keeps people out it is also understood as a connection between the community and outsiders.

At the communal garden the fence has a similar double role. There, the fence is used as a mechanism to respond to conflict in the group. When certain members cause friction, the access code is changed to exclude them. The code on the padlock is also changed when the group’s cohesion is floundering. When gardeners who attend the communal hours perceive that others choose to garden outside of those hours too much the code is changed because people then have to visit the garden during general hours again when other community garden members are also there. It coerces people back into a community gardening rhythm. 
Gardeners at all three projects express moral objections against fences, especially in the context of projects that aim to be for the community. Talking about the fence, Hellen at the private plot garden says:

'I feel that when I'm in here or just like when I walk past, people look in, but it's not a look-in as though... It's kind of like an us and a them or 'oh she is allowed in that garden space' or 'what is that garden space?' Or there doesn’t seem to be like, it doesn’t seem to achieve what is set out to in that it's a community garden. It feels like it’s an exclusive club of gardeners rather than something for everyone’. (Hellen, 29, Stanley Road Garden)

For outsiders access to PARK STREET GARDEN is limited to the communal gardening hours and gardeners feel that their efforts and the entitlement that those efforts bring, should weigh heavier than the project's aim of establishing community connections. Charles says: 'I don't think community gardens should be open to anyone to just stroll through at any time anyway, because it's not a public garden, it's a community garden, there is a reward for effort that goes on, that should go on here. And I don't think that there should be an unlimited entitlement to people who are not involved in that to wander through it. But I don't know whether that has an effect on how many people don't wander through’. (Charles, 29, Park Street Garden)

Here, Charles describes that the effort that gardeners invest in the garden legitimatises their exclusive access to the space, even when that exclusivity might prevent new people from starting to invest similar efforts and thus 'earn' their access to the space. At the private plot garden Henry says something similar when we talk about whether the space functions as a leisure space:

'I wouldn’t want it too comfortable in here for seating as people might come in here and sit down on a seat and after the pubs closed. To come in with a bottle of beer and 
sit and drink it. I wouldn't like it develop into something like that. So. We don’t need fancy seats. [...] Well relaxing a bit for the gardeners I guess if they want to sit down and have a coke, or bring a coffee in here or something during the day you know'. (Henry, 76, Stanley Road Garden)

Like Charles, Henry voices a perceived difference between a group of hard-working gardeners, entitled to the garden space on the grounds of the labour they invest and a group of non-deserving others who should be kept out.

Fencing practices such as gardeners talking about the fence, engaging with people through the fence and changing the codes on locks, illustrates the uneasy and contradictory functioning of fences in these community gardens. The fences keep people out and this seems warranted to some of the gardeners, but at the same time connections between gardeners and passers-by are made through the fence. Fences facilitate the existence of the community projects and generate a sense of legitimacy. The labour that gardeners invest into the garden space creates a common interest to protect that space, even where protective fencing might from a potential barrier to new gardeners who seek to invest their effort.

\section{$\underline{\text { Discussion and conclusions }}$}

Much community garden research either advocates for these projects on the ground of their inclusionary social effect (Beilin and Hunter, 2011; Firth et al., 2011; Glover et al., 2005; Holland, 2004) or highlight how they facilitate roll-back neoliberalism (e.g. Rosol, 2012). Scholarly work puts forward interpretations of community gardens as inclusive spaces or community commons by virtue of their position in an institutional landscape (e.g. Schmelzkopf, 2002; Eizenberg, 2013). These studies emphasise relations of community gardens to external property regimes. Drawing from property theory that engages with practice (Blomley, 2013) and building on work that has emphasised the relationship between 
1 gardening practices and property (Blomley, 2004; Lang, 2014), the empirical exploration of three gardening practices, creates insight into how property relations are produced in relational and contradictory ways by the gardeners.

A focus on practised connections between private and community garden spaces

illustrates how community gardens are the product of practices that create contradicting and relational property constructs. Rather than isolated pockets of alternative values and practices, community gardens are constituted by people who are simultaneously engaged in various property spaces and relationships. Gardeners move back and forth between those spaces as they garden in community gardens. These relationships and associated practices translate into gardening practices, such as plotting and fencing through which the community space is connected to the larger landscape of property relationships. Interactions with the garden space, transplanting plants between home and community gardens and arranging plants onto plots, help fit the communal gardens into autonomous personal lifestyles, and work towards the creation of a community that comprises different practices of property. Because property practices are multiple and relational, community gardens are not inherently inclusive or exclusive. My research shows that property creates legitimacy and group belonging, but also shows the potential exclusionary effects of property practices in community gardens. Garden membership can be limited to people who can afford rent or have time available to invest in demonstrating their community-mindedness. Overlapping practices between private and communal garden spaces also challenge the membership of people who live at a greater distance from the garden. Exclusive access to an individual plot makes it easier for community gardeners to fit gardening in with other personal lifestyle choices but also reproduces a tragedy of the commons discourse that favours a reading of communal ownership as inefficient or wasteful. Communal understandings and practices of 
1 property, although present and necessary in these spaces, are discursively less successful as a consequence of this reproduction.

Even where gardeners aim to create an inclusive community space, property practices unwittingly create both connections and barriers. For example, these gardeners find it important to have community connections and try to build relationships with other neighbourhood stakeholders and organisations, but at the same time many endorse fences as inevitable boundaries between themselves and the neighbourhood community with which they try to connect. On the one hand, property can work to create an inclusive and cohesive group, but on the other hand these practices also create defensive and exclusionary attitudes towards outsiders.

The gardening practices I presented here problematize readings of community gardens as either inherently inclusive or as perpetuating neoliberal hegemony. The focus on practices in community gardens shows that these projects comprise community-mindedness as well as practices driven by self-interest. It is not the purpose of this paper to undermine the important contributions of community garden and public space scholarship. On the contrary, I hope it demonstrates that community gardens are connected to the larger urban fabric with all its intricacies spanning from everyday routines, property investments and social relationships. Contradictory and exclusionary practices are not discussed with the purpose of arguing against the value of community gardening projects. Instead, I believe that a fuller understanding of those tensions will lead to insight into how such community-led initiatives can be made more sustainable and inclusive. Rather than framing property in community gardens as either exclusively private or as community commons, the work presented here encourages future critical inquiry into the various contradictory relationships that are produced through property practices and how those might be motivated by individual and community interests in simultaneous and complex ways. 
2 Acknowledgments. I am grateful to Lesley Head and Leah Gibbs for their generous support and advice. Thank you to the participants who contributed their time and thoughts towards this research. I also wish to thank Sophie-May Kerr who commented on a previous draft, and three anonymous reviewers whose suggestions helped me improve the paper.

6

7 The author received financial support from the Australian Research Council, grant number FL0992397.

$\underline{\text { References }}$

Atkinson R, Wulff, M, Reynolds M, Spinney A, 2011, “Gentrification and displacement: the household impacts of neighbourhood change” AHURI Final Report No. 160 (Australian Housing and Urban Research Institute: Melbourne)

Beilin R, Hunter A, 2011, “Co-constructing the sustainable city: how indicators help us 'grow' more than just food in community gardens” Local Environment 16(6) 523-538

Blomley N, 2004, “Un-real estate: proprietary space and public gardening” Antipode 36(4) 614-641

Blomley N, 2013, “Performing Property: Making the World” Canadian Journal of Law and Jurisprudence 27(1) 23-48

Blomley N, 2015, “The territory of property” Progress in Human Geography Advance online publication: 10.1177/0309132515596380

Blomley, N, 2016, “The Boundaries of Property: Complexity, Relationality, and Spatiality” Law and Society Review 50(1) 224-256

Cerwonka A, 2004 Native to the Nation: disciplining landscapes and bodies in Australia (University of Minnesota Press, Minneapolis, MN) 
1 City of Sydney, 2011 “Profile.id” Accessed January 2016 via http://profile.id.com.au/sydney/

2 City of Sydney, 2016 “Community gardens” Accessed February 2016 via http://www.cityofsydney.nsw.gov.au/community/participation/community-gardens

Davies M, 2012, “Persons, property, and community” Feminists@law 2(2): 1-21

Delaney D, 2002, “Beyond the world: law as a thing of this world”, in Law and Geography volume 5 Eds J Holder, C Harrison (Oxford University Press, Oxford) pp 67-83

Eizenberg E, 2012. “Actually Existing Commons: Three Moments of Space of Community Gardens in New York City” Antipode 44(3) 764-782

Firth C, Maye D, Pearson D, 2011, “Developing ‘community’ in community gardens” Local Environment 16(6) 555-568

Glover T, Shinew K, Parry D, 2005, “Association, Sociability, and Civic Culture: the democratic effect of community gardening” Leisure Sciences 27(1) 75-92

Guitart D, Pickering CM, Byrne J, 2014, “Color me healthy: food diversity in school community gardens in two rapidly urbanising Australian cities” Health \& Place 26 110117

Guthman J, 2004, “Back to the Land: The Paradox of Organic Food Standards.” Environment and Planning A 36(3) 511-28

Head L M, Muir P, 2006, “Suburban Life and the Boundaries of Nature: Resilience and Rupture in Australian Backyard Gardens” Transactions of the Institute of British Geographers 31(4) 505-524

Holland L, 2004, "Diversity and connections in community gardens: a contribution to local sustainability” Local Environment 9(3) 285-305

Kingsley J, Townsend M, 2006, “’Dig In’ to Social Capital: Community Gardens as Mechanisms for Growing Urban Social Connectedness” Urban Policy and Research, 24(4) 525-537 
1 Klein B, 1993, "Fences, Fertilizers, and Foreigners: Moral Dilemmas in the Swedish Cultural Landscape” Journal of Folklore Research 30(1) 45-59

Kurtz,H, 2001, “Differentiating Multiple Meanings of Garden and Community” Urban Geography 22(7) 656-670

Kusenbach M, 2003, “Street Phenomenology: The Go-along as Ethnographic Research Tool” Ethnography 4(3) 455-485

Lang U, 2014, “The Common Life of Yards” Urban Geography 35(6) 852-869

Lawson L, 2007, “Cultural Geographies in Practice The South Central Farm : Dilemmas in Practicing the Public” Cultural Geographies 14 611-16

McClintock N, 2014, "Radical, Reformist, and Garden-Variety Neoliberal: Coming to Terms with Urban Agriculture’s Contradictions” Local Environment: The International Journal of Justice and Sustainability 19(2) 147-71

Naylor L, 2012, “Hired Gardens and the Question of Transgression: Lawns, Food Gardens and the Business of 'Alternative’ Food Practice.” Cultural Geographies 19(4) 483-504

Nedelsky J, 1990, “Law, Boundaries, and the Bounded Self” Representations (30) 162-189

Pudup M B, 2008, “It Takes a Garden: Cultivating Citizen-Subjects in Organized Garden Projects” Geoforum 39(3) 1228-1240

Quastel N, 2009, “Political Ecologies of Gentrification” Urban Geography 30(7) 694-725

Rose C, 1994, Property and Persuasion: essays on the history, theory, and rhetoric of ownership. Boulder, CO: Westview.

Rosol M, 2012, “Community volunteering as neoliberal strategy? green space production in Berlin” Antipode 44(1) 239-257

Schmelzkopf K, 1995, “Urban community gardens as contested space” Geographical Review 85(3) 364-381 
1 Schmelzkopf K, 2002, "Incommensurability, Land Use, and the Right to Space: Community Gardens in New York City" Urban Geography 23(4) 323-343

Staeheli L, Mitchell D, 2008 The people's property? Power, politics and the public.

4 (Routlegde, New York)

5 Turner B, 2011, "Embodied connections: sustainability, food systems and community gardens” Local Environment, 16(6) 509-522

Waitt G, Gill N, Head L, 2009, “Walking Practice and Suburban Nature-Talk” Social \& Cultural Geography 10(1) 41-60

Wekerle G R, Classens M, 2015, "Food production in the city: (re)negotiating land, food and property” Local Environment 20(10) 1175-1193 